\title{
Chronic exposure to ketamine induces neuronal lose and glial reaction in CA4 region of hippocampus
}

\author{
AHMADPOUR $S H .{ }^{1 *}$, FOGHI, $\mathrm{K}^{1}{ }^{1}$ and BEHRAD, A. ${ }^{2}$ \\ ${ }^{1}$ Anatomy Department, Medicine School, North Khorasan University of Medical Sciences Bojnurd, Iran \\ ${ }^{2}$ Medicine School, North Khorasan University of Medical Sciences Bojnurd, Iran \\ *E-mail: shahahmadpour@gmail.com
}

\begin{abstract}
Introduction: Studies have shown that even acute single dose of ketamine is associated with neurodegeneration in hippocampus. The aim of this study was to examine the effects of chronic exposure to ketamine on hippocampus proper in young adult male rats. Materials and Method: Twenty young adult male wistar rats weighing $120-150 \mathrm{~g}$ were randomly divided into two groups. Experimental group received ketamine intraperitoneally at the dose of $10 \mathrm{mg} / \mathrm{kg}$ for one week. The control animals only received saline. At the end of week animals were anesthetized and the hippocampus and adrenal were harvested for further study. Results: Cytological examination of cresyl violet stained sections of ketamine group showed dark neurons in CA4 region. The number of dark neurons in CA4 $(15 \pm 3)$ showed meaningful difference with control $(\mathrm{P}<0.001)$. The weight of wet brain in ketamine group $(1.34 \pm 0.04 \mathrm{gr})$ showed significant level of difference in comparison with those of control $(1.6 \pm .2 \mathrm{gr})(\mathrm{P}<0.05)$. The presence of oligodendrocytes aggregation around degenerating and healthy looking neurons was only recognized in ketamine group. Also in ketamine exposed animals, hypertrophic astrocytes especially in white matter hilar region, were observed. Conclusion: According to our findings it could be concluded repeated or chronic ketamine use is associated neurodegeneration in CA4region of hippocampus and sever glial reaction.
\end{abstract}

Keywords: ketamine, hippocampus, CA4, oligodendrocytes, astrocytes.

\section{Introduction}

Ketamine is an anesthetic drug which is used widely in dissociative anesthesia (JOE-LAIDLER and HUNT, 2008). As an ionotropic glutamergic N-methyl- D- aspartate receptors (NMDAR) antagonist, ketamine administration evokes cognitive deficits similar to schizophrenia (KRYSTAL, KARPER, SEIBYL et al., 1994). Due to psychotogenic effects and resulted euphoria, ketamine is used as a recreational abused substance. According to reports use of ketamine as a club drug is dramatically increasing, so its long term side effects generate a new major concerns in many countries (SCHIFANO, CORKERY, OYEFESO et al., 2008). Recent evidence suggest that ketamine effects on central nervous system are not solely restricted to memory or cognitive impairment and its abuse could lead to profound structural abnormalities and neurodegeneration in brain structures involved in memory and emotional behaviors (IBLA, HAYASHI, BAJIC et al., 2009; LIAO, TANG, CORLETT et al., 2011; JEVTOVIC-TODOROVIC, HARTMAN, IZUMI et al., 2003). One of the critical regions implicated in memory processes and emotional behaviors is hippocampal formation (GLUCK and MYERS, 1995). Structurally hippocampal formation consists of dentate gyrus and hippocampus proper or cornus ammonis (CA). Cornus ammonis itself is segmented into four distinct areas, CAl-CA4, with different vulnerability to various insults (EL FALOUGY, KUBIKOVA and BENUSKA, 2008). Study has shown that ketamine use in healthy volunteers disrupts hippocampal contribution in memory retrieval and decoding (HONEY, HONEY, O'LOUGHLIN et al., 2005). Recently it has been shown that acute ketamine use induces tau hyperphosphorylation in the hippocampal neurons (JIN, HU,
DONG et al., 2013). Tau is an intermediate neurofilament which its abnormal phosphorylated or hyperphophrylated forms are major constituent of neurofibrillary tangle (NFT) observed in Alzheimer's disease (LE FRECHE, BROUILLETTE, FERNANDEZ-GOMEZ et al., 2012). It has been suggested ketamine - induced neurodegeneration is mediated through the oxidative stress process (ZUO, WU, YAO et al., 2007). Previous studies have well documented that hippocampus is sensitive to conditions associated with increased oxidative stress and free radicals generation (AHMADPOUR and HAGHIR, 2011). With regard to lack of protective mechanism against free radicals in neurons, we hypothesized chronic ketamine exposure may lead to pathologic changes in neuro- glial elements. Given that the little data on effects of chronic ketamine exposure on hippocampus proper in one hand and importance of these structure in memory on the other hand, we aimed to examine effects of chronic ketamine exposure on glial cells reaction and pyramidal layer of cornus ammonis regions of hippocampus in young adult male rats.

\section{Methods}

This experimental study was carried out on 20 male wistar rats (4 weeks old 120-150 gr). The animals were housed five per cage with food and water available ad libitum and maintained on a $12 \mathrm{~h}$ light/dark cycle. Animals were involved in this experiment in accordance with the Guide for Care and Use of Laboratory Animals of North Khorasan Ethic Committee. Animals were randomly divided into two groups namely experimental and control. Experimental group 
received ketamine intraperitoneally at dose of $10 \mathrm{mg} / \mathrm{kg}$ (PROESCHOLDT, HEIMANN and KEMPSKI, 2001) for 7 days. The control animals only received saline. At the end of week animals were anesthetized by chloroform. The brain and adrenal gland of each animal were removed carefully and immediately weighted. The harvested brains were fixed in formalin $10 \%$ neutral formalin for 14 hours at $4 \mathrm{C}$. Paraffin embedded sections (bregma $-1.8 \mathrm{~mm}$ to $-3.8 \mathrm{~mm}$ ) of $10 \mu \mathrm{m}$ thickness were cut on microtome. Subsequently sections were sampled according to systematic random sampling (SSR) and stained with cresyl violet for demonstration of nerve cell bodies. Quantitative analysis of degenerated dark neurons in the pyramidal cell layer of cornus ammonis of hippocampus was performed, using calibrated ocular micrometer. Dark neurons were counted by an investigator who was blinded to the study. In order to study the glial elements the white matter of hilar region and whole hippocampus proper were examined under light microscopy.

\subsection{Statistical analysis}

The obtained results were expressed as mean \pm SD. Statistical analyses were conducted by Statistical Product for Social Sciences (SPSS version 17.0). Differences were considered to be significant at $\mathrm{P}<0.05$. Correlation between the values was estimated by Pearson's correlation.

\section{Results}

\subsection{Quantitative findings}

The weight of wet brain in ketamine group $(1.34 \pm 0.04 \mathrm{gr})$ showed meaningful difference in comparison with control (1.6 \pm .2 gr $)(\mathrm{P}<0.05)$. Hippocampal subfields including CAl-CA4 were defined and examined under light microscopy. Cytological examination of cresyl violet stained sections of ketamine group showed dark neurons in CA4 region. Hyperstained dark neuron were evident with contracted, hyperchromatic appearance and vacuolated space (Figures 1,2). The number of dark neurons in CA4 $(15 \pm 3)$ showed meaningful difference with control (Figure 3$)(\mathrm{P}<0.001)$. The number of dark neurons in CAl-3 regions of ketamine group was not significant. Unilateral adrenal weight of ketamine group $(42.6 \pm 7.33 \mathrm{mg})$ showed significant level of difference with those of control animals $(18 \pm 1.22 \mathrm{mg})(\mathrm{P}<0.001)$. The weight of wet brain in ketamine group $(1.34 \pm 0.04 \mathrm{gr})$ showed meaningful difference in comparison with control $(1.6 \pm .2 \mathrm{gr})(\mathrm{P}<0.05)$. There was a strong connection between the weights of adrenal and brains in ketamine group $(\mathrm{r}=-.93)$.

\subsection{Descriptive histopathology of glial cells}

Another prominent microspic finding in the case group was glial cell particularly oligodendrocytes aggregation around degenerating and healthy looking neurons. These features were only recognized in ketamine group (Figures 4, 5). Also in ketamine exposed animals, hypertrophic astrocytes especially in white matter hilar region, were evident (Figure 5).

\section{Discussion}

The results of our current study revealed that one week ketamine exposure induces dark neurons formation in CA4 region of hippocampus. Additionally our findings showed that repeated ketamine exposure is associated with glial reaction in

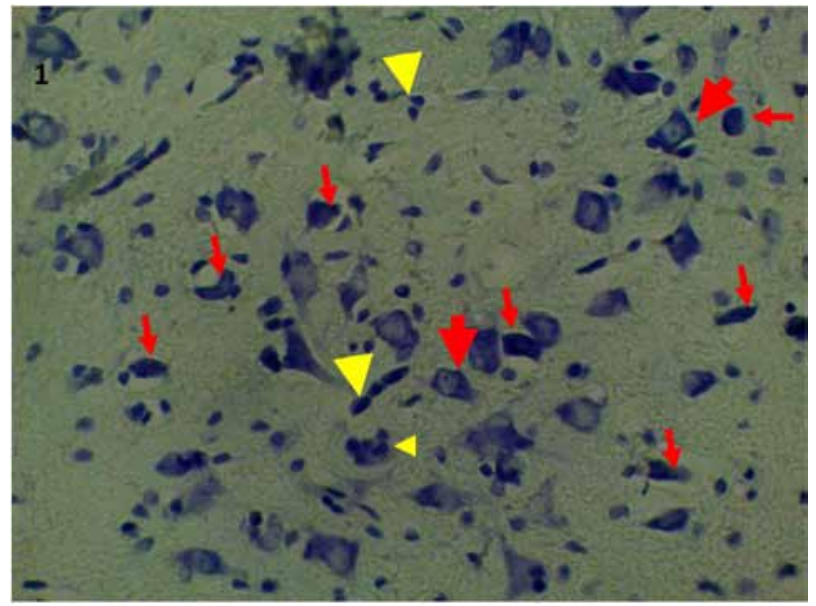

Figure 1. degenerated neurons in vacuolated space (thin arrows) and oligodendrocytes aggregation (arrow heads) in hilar region of ketamine group. some scattered normal neurons (thick arrows) are seen. X40.

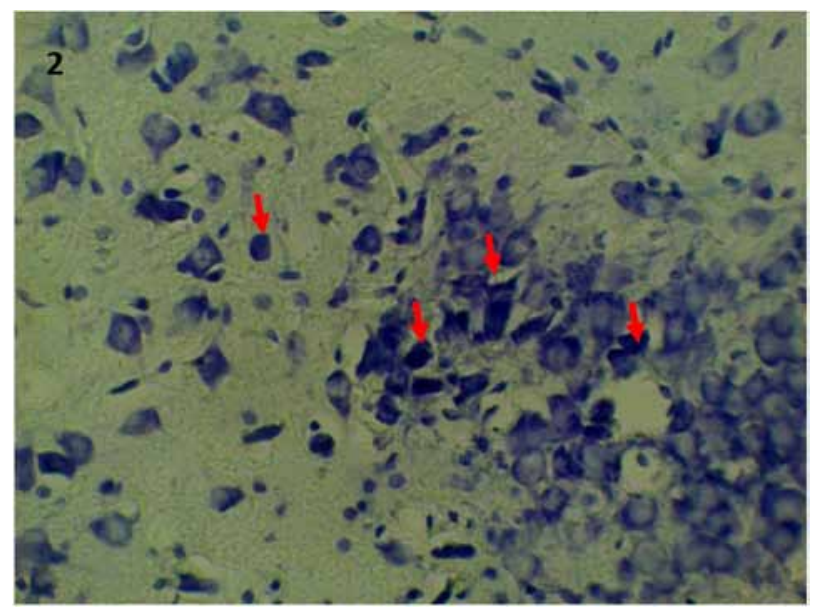

Figure 2. Degenerated dark neurons (thin arrows) CA4 region of ketamine group. X40.

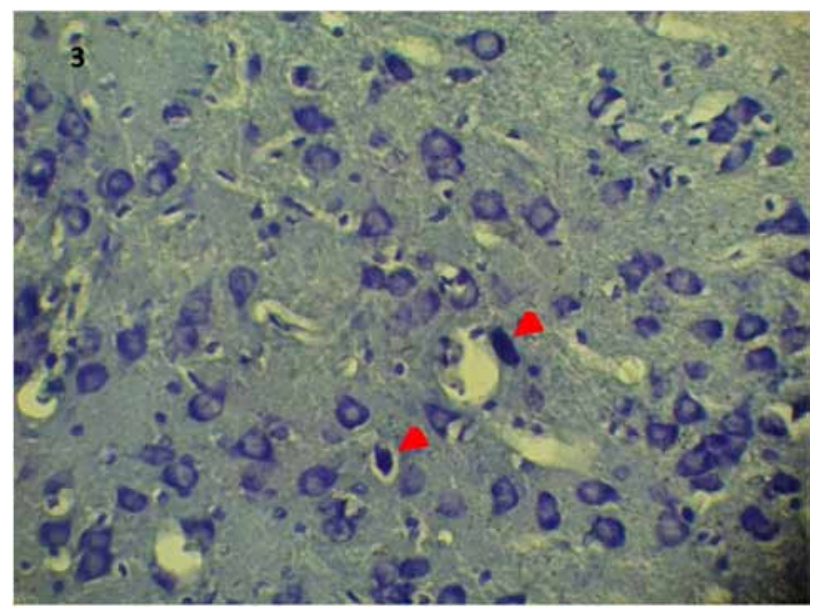

Figure 3. Hilar region in control group. Few degenerated dark neurons are seen (arrow heads). X40. 


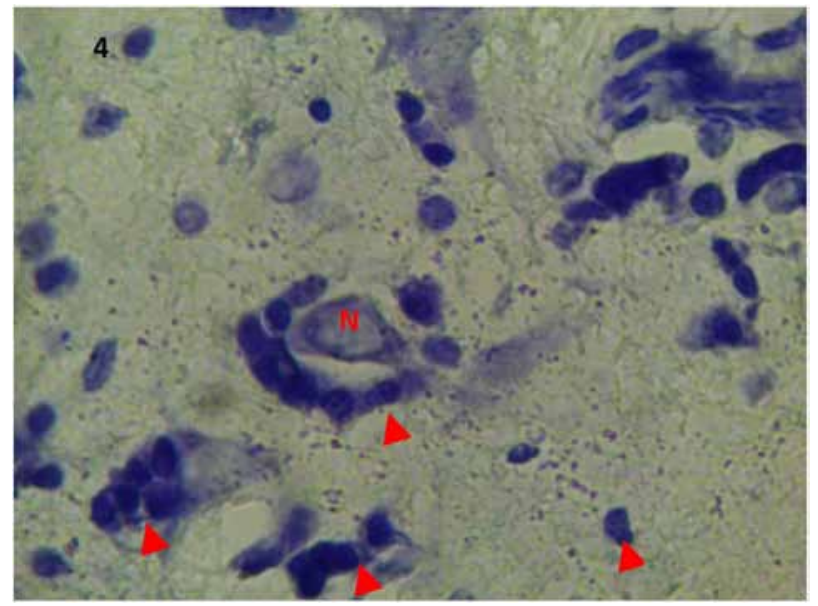

Figure 4. Oligodendrocytes aggregation (arrows head). A healthy looking neuron with several oligodendrocytes are seen in ketamine group. X100.

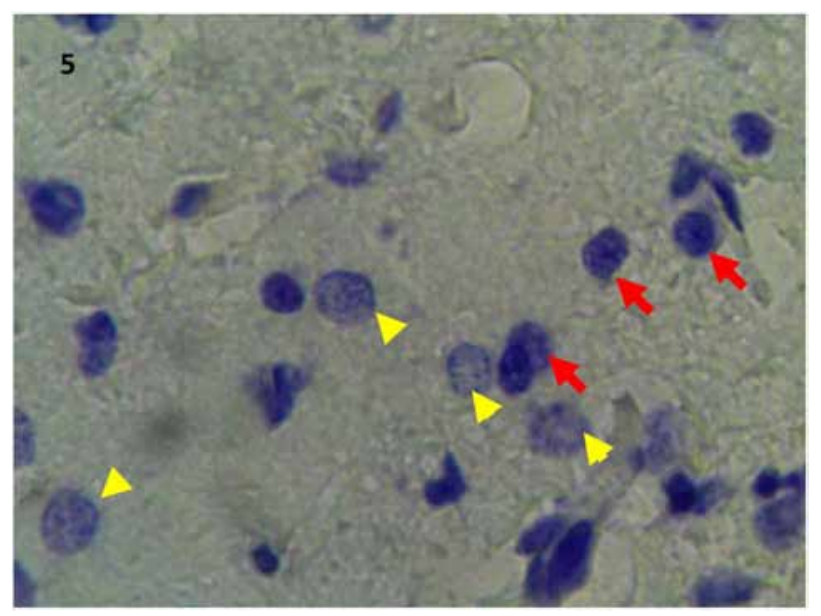

Figure 5. Hypertrophic astrocytes (arrows head) and oligodendrocytes (arrows) in hilar region of ketamine group. X100.

white matter of hilar region of hippocampus. Ketamine- induced neurodegeneration has been evaluated in previous studies. Ibla, Hayashi, Bajic et al. (2009) showed that ketamine use in rat pups is associated with increased rate of neurodegeneration in different cortical and subcortical regions. Majewski-Tiedeken, Rabin and Siegel (2008) demonstrated Ketamine- induced neurodegeneration in CA3 region of mice after ketamine exposure. The results of our study are compatible with previous reports on ketamine- induced neurodegeneration and underline the neurotoxic effects of chronic ketamine use on nervous tissue. Thus far this is probably first report on ketamine induced neurodegeneration in CA4 area of hippocampus. We cannot explain the reason for selective neuronal lose in CA4, but the discrepancy between our results and Tiedeken 's report on CA3 neuronal lose after ketamine exposure may be accountable by species difference, duration of ketamine exposure, dose of ketamine, and also regional differences of cornus ammonis (PEREIRA, VALLS-PEDRET, ROS et al., 2014). In this study microscopic examination revealed fresh dark neurons with hyperchromatic dark appearance, sharp margins and compacted nuclei. Dark neurons formation has been reported in various neurologic and pathometabolic disorders. Several lines of evidence suggest that their occurrence is related with glutamate toxicity and oxidative stress (AHMADPOUR and HAGHIR, 2011). Although ketamine is known as a competitive NMADA receptor antagonist, its use is associated with increased glutamate in presynaptic zone, escalating accumulation of presynaptic glutamate and subsequently increased oxidative stress levels (ZUO, WU, YAO et al., 2007; MOGHADDAM, ADAMS, VERMA et al., 1997). Therefore prolonged ketamine use could be considered as an exogenous stressor. Experimental studies have demonstrated that exogenous and endogenous stressor may interrupt regulatory role of hippocampus on hypothalamo-pituitary-adrenal axis (HPA) which in turn increases corton level. Increased plasma level of glucocorticoids imposes adverse effects on hippocampus (HUANG, LUI, CHANG et al., 2009). Although due to some technical limitations we could not perform corton assay in animals, massive adrenal hypertrophy in ketamine group may reflect a disturbance in HPA. Additionally our microscopic findings revealed reactive changes in glial elements in particular astrocytes and oligodendrocyte. Astrocytes are heterogeneous glial cells population in the central nervous system. They play a key role in regulation of neurotransmitters, antioxidant Production and glutamate uptake in the CNS (OBERHEIM, GOLDMAN and NEDERGAARD, 2012). Altered function of astrocytes has been documented in neuroinflammatory and neurodegenerative disorders in which there is a dramatic increase in free radical generation (SHIBATA and KOBAYASHI, 2008). Considering ketamine induces symptoms similar to schizophrenia in one hand and reported pathological changes of astrocytes in schizophrenia give an emphasis on the role of oxidative stress in pathogenesis and progress of schizophrenia (POWELL, SEJNOWSKI and BEHRENS, 2012). Recent finding suggest the same role for oligodendrocytes in developing psychiatric disorders such mood disorder and schizophrenia (URANOVA, VOSTRIKOV, ORLOVSKAYA et al., 2004). Genetic and imaging studies have documented evidence suggesting disruption of oligodendrocytes in schizophrenia (HAROUTUNIAN, KATSEL, DRACHEVA et al., 2007). Moreover oligodendrocytes monitor neuronal activity through the various receptors including NMDA and AMPA (EDGAR and SIBILLE, 2012). Interestingly ketamine use is associated with increase in ratio of AMPA to NMDA receptors (TIZABI, BHATTI, MANAYE et al., 2012). Thus the observed glial cells abnormalities may mirror the fact that glial cells are at the center of pathogenesis of psychiatric disorders like schizophrenia (BERNSTEIN, STEINER and BOGERTS, 2009). Another interesting findings of this study was related to reduction of brain's weight. Although we could not find similar reports on effects of ketamine use on whole brain's weight, this sort of data should be interpreted cautiously. Brain atrophy is a deteriorating phenomenon reported in devastating neurodegenerative disorders like Alzehiemrs' diseases (LEUNG, BARTLETT, BARNES et al., 2013). Recently it is demonstrated single dose of ketamine induce tau hyperphosphorylation and structural abnormalities in cytoskeleton (HUANG, LUI, CHANG et al., 2009). Tau is a microtubule associated proteins which plays a pivotal role in memory and neuronal viability (SULTAN, NESSLANY, VIOLET et al., 2011). Also in a recent study 
demonstrated that mutant tau gene result in neuronal loss, brain atrophy and memory impairment (VAN DER JEUGD, AHMED, BURNOUF et al., 2011). Obviously we could not attribute the decreased brain's weight to only neuronal lose and presumably other factors such as change in water content of brain and white matter change s (AKIYAMA, MEYER, MORTEL et al., 1997) should take into consider.

\section{Conclusion}

Repeated or chronic ketamine use imposes deleterious effects on CA4 region of hippocampus. This scenario is also associated with glial reaction and neuro-endocrine axis involvement. Given the widespread use ketamine as anesthetic drug and also a recreational drug, therefore we suggest a comprehensive study to evaluate effects of ketamine on whole brain tissue and possible underlying molecular mechanism.

Acknowledgements: This study was supported by deputy of research of North Khorasan University of Medical Sciences.

\section{References}

AHMADPOUR, SH. and HAGHIR, H. Diabetes mellitus type 1 induces dark neuron formation in the dentate gyrus: a study by Gallyas' method and transmission electron microscopy. Romanian Journal of Morphology and Embryology, 2011, vol. 52, n. 2, p. 575579. PMid:21655645.

AKIYAMA, H., MEYER, JS., MORTEL, KF., TERAYAMA, Y., THORNBY, JI. and KONNO, S. Normal human aging: factors contributing to cerebral atrophy. Journal of the Neurological Sciences, 1997, vol. 152, n. 1, p. 39-49. http://dx.doi.org/10.1016/S0022 510X(97)00141-X. PMid:9395125.

BERNSTEIN, HG., STEINER, J. and BOGERTS, B. Glial cells in schizophrenia: pathophysiological significance and possible consequences for therapy. Expert Review of Neurotherapentics, 2009, vol. 9, n. 7, p. 1059-1071. http://dx.doi.org/10.1586/ern.09.59. PMid:19589054.

EDGAR, N. and SIBILLE, E. A putative functional role for oligodendrocytes in mood regulation. Translational Psychiatry, 2012, vol. 2, n. 5, p. el09. http://dx.doi.org/10.1038/tp.2012.34. PMid:22832953.

EL FAlOUGY, H., KUBIKOVA, E. and BENUSKA, J. The microscopical structure of the hippocampus in the rat. Bratislavske Lekárske Listy, 2008, vol. 109, n. 3, p. 106-110. PMid:18517132.

GLUCK, MA. and MYERS, CE. Representation and association in memory: a neurocomputational view of hippocampal function. Current Directions in Psychological Science, 1995, vol. 4, n. 1, p. 23-29. http:// dx.doi.org/10.1111/1467-8721.ep10770958.

HAROUTUNIAN, V., KATSEL, P., DRACHEVA, S., STEWART, DG. and DAVIS, KL. Variations in oligodendrocyte-related gene expression across multiple cortical regions: implications for the pathophysiology of schizophrenia. The International Journal of Neuropsychopharmacology, 2007, vol. 10, n. 4, p. 565-573. http:// dx.doi.org/10.1017/S1461145706007310. PMid:17291370.

HONEY, GD., HONEY, RA., O'LOUGHLIN, C., SHARAR, SR., KUMARAN, D., SUCKLING, J., MENON, DK., SLEATOR, C., BULLMORE, ET. and FLETCHER, PC. Ketamine disrupts frontal and hippocampal contribution to encoding and retrieval of episodic memory: an fMRI study. Cereb Cortex., 2005, vol. 15, n. 6, p. 749759. http://dx.doi.org/10.1093/cercor/bhhl76. PMid:15537676.

HUANG, CW., LUI, CC., CHANG, WN., LU, CH., WANG, YL. and CHANG, CC. Elevated basal cortisol level predicts lower hippocampal volume and cognitive decline in Alzheimer's disease.
Journal of Clinical Neuroscience, 2009, vol. 16, n. 10, p. 1283-1286. http://dx.doi.org/10.1016/j.jocn.2008.12.026. PMid:19570680.

IBLA, JC., HAYASHI, H., BAJIC, D. and SORIANO, SG. Prolonged exposure to ketamine increases brain derived neurotrophic factor levels in developing rat brains. Current Drug Safety, 2009, vol. 4, n. 1, p. 11-16. http://dx.doi.org/10.2174/157488609787354495. PMid:19149520.

JEVTOVIC-TODOROVIC, V., HARTMAN, RE., IZUMI, Y., BENSHOFF, ND., DIKRANIAN, K., ZORUMSKI, CF., OLNEY, JW. and WOZNIAK, DF. Early exposure to common anesthetic agents causes widespread neurodegeneration in the developing rat brain and persistent learning deficits. The Journal of Neuroscience, 2003, vol. 23, n. 3, p. 876-882. PMid:12574416.

JIN, H., HU, Z., DONG, M., WU, Y., ZHU, Z. and XU, L. Ketamine induces tau hyperphosphorylation at serine 404 in the hippocampus of neonatal rats. Neural Regeneration Research, 2013, vol. 8, n. 17, p. 1590-1596. PMid:25206455.

JOE-LAIDLER, K. and HUNT, G. Sit Down to float: the cultural meaning of ketamine use in Hong Kong. Addiction Research and Theory, 2008, vol. 16, n. 3, p. 259-271. http://dx.doi. org/10.1080/16066350801983673. PMid:19759834.

KRYSTAL, JH., KARPER, LP., SEIBYL, JP., FREEMAN, GK., DELANEY, R., BREMNER, JD., HENINGER, GR., BOWERS, MB Jr. and CHARNEY, DS. Subanesthetic effects of the noncompetitive NMDA antagonist, ketamine, in humans: psychotomimetic, perceptual, cognitive, and neuroendocrine responses. Archives of General Psychiatry, 1994, vol. 51, n. 3, p. 199-214. http://dx.doi.org/10.1001/ archpsyc.1994.03950030035004. PMid:8122957.

LE FRECHE, H., BROUILLETTE, J., FERNANDEZ-GOMEZ, F-J., PATIN, P., CAILLIEREZ, R., ZOMMER, N., SERGEANT, N., BUÉE-SCHERRER, V., LEBUFFE, G., BLUM, D. and BUÉE, L. Tau phosphorylation and isoflurane anesthesia: an association to postoperative cognitive impairment. Anesthesiology, 2012, vol. 116, n. 4, p. 779-787. http://dx.doi.org/10.1097/ALN.0b013e31824be8c7. PMid:22343471.

LEUNG, KK., BARTLETT, JW., BARNES, J., MANNING, EN., OURSELIN, S. and FOX, NC. Cerebral atrophy in mild cognitive impairment and Alzheimer disease: rates and acceleration. Neurology, 2013, vol. 80, n. 7, p. 648-654. http://dx.doi.org/10.1212/ WNL.0b013e318281ccd3. PMid:23303849.

LIAO, Y., TANG, J., CORLETT, PR., WANG, X., YANG, M., CHEN, H., LIU, T., CHEN, X., HAO, W. and FLETCHER, PC. Dorsal prefrontal gray matter after chronic ketamine use. Biological Psychiatry, 2011, vol. 69, n. 1, p. 42-48. http://dx.doi.org/10.1016/j. biopsych.2010.08.030. PMid:21035788.

MAJEWSKI-TIEDEKEN, CR., RABIN, CR. and SIEGEL, SJ. Ketamine exposure in adult mice leads to increased cell death in $\mathrm{C} 3 \mathrm{H}$, DBA2 and FVB inbred mouse strains. Drug, 2008, vol. 92, n. 1-3, p. 217-227. PMid:17920787.

MOGHADDAM, B., ADAMS, B., VERMA, A. and DALY, D. activation of glutamatergic neurotransmission by ketamine: a novel step in the pathway from NMDA receptor blockade to dopaminergic and cognitive disruptions associated with the prefrontal cortex. The Journal of Neuroscience, 1997, vol. 17, n. 8, p. 2921-2927. PMid:9092613.

OBERHEIM, NA., GOLDMAN, SA. and NEDERGAARD, M. Heterogeneity of astrocytic form and function. Methods in Molecular Biology, 2012, vol. 814, p. 23-45. http://dx.doi.org/10.1007/9781-61779-452-0_3. PMid:22144298.

PEREIRA, JB., VALLS-PEDRET, C., ROS, E., PALACIOS, E., FALCÓN, C., BARGALLÓ, N., BARTRÉS-FAZ, D., WAHLUND, LO., WESTMAN, E. and JUNQUE, C. Regionavulnerability of hippocampal subfields to aging measured by structural and diffusion. MRI Hippocampus., 2014, vol. 24, n. 4, p. 403-414. PMid:24339261. 
POWELL, SB., SEJNOWSKI, TJ. and BEHRENS, MM. Behavioral and neurochemical consequences of cortical oxidative stress on parvalbumin-interneuron maturation in rodent models of schizophrenia. Neuropharmacology, 2012, vol. 62, n. 3, p. 1322-1331. http:// dx.doi.org/10.1016/j.neuropharm.2011.01.049. PMid:21315745.

PROESCHOLDT, M., HEIMANN, A. and KEMPSKI, O. Neuroprotection of $S(1)$ ketamine isomer in global forebrain ischemia. Brain Research, 2001, vol. 904, n. 2, p. 245-251. http://dx.doi. org/10.1016/S0006-8993(01)02465-9. PMid:11406122.

SCHIFANO, F., CORKERY, J., OYEFESO, A., TONIA, T. and GHODSE, AH. Trapped in the "K-hole": overview of deaths associated with ketamine misuse in the UK (1993-2006). JClin Sychopharmacol., 2008, vol. 28, n. 1, p. 114-116. PMid:18204359.

SHIBATA, N. and KOBAYASHI, $M$. The role for oxidative stress in neurodegenerative diseases. Brain and Nerve, 2008, vol. 60, n. 2, p. 157-170. PMid:18306664.

SULTAN, A., NESSLANY, F., VIOLET, M., BEGARD, S., LOYENS, A., TALAHARI, S., MANSURGLU, Z., MARZIN, D., SERGEANT, N., HUMEZ, S., COLINS, M. and BONNEFOY, E. Nuclear tau, a key player in neuronal DNA protection. The Journal of Biological Chemistry, 2011, vol. 286, n. 6, p. 4566-4575. http://dx.doi. org/10.1074/jbc.M110.199976. PMid:21131359.

TIZABI, Y., BHATTI, BH., MANAYE, KF., DAS, JR. and AKINFIRESOYE, L. Antidepressant-like effects of low ketamine dose is associated with increased hippocampal AMPA/NMDA receptor density ratio in female Wistar-Kyoto rats. Neuroscience, 2012, vol. 213, p. 72-80. http://dx.doi.org/10.1016/j.neuroscience.2012.03.052. PMid:22521815.

URANOVA, NA., VOSTRIKOV, VM., ORLOVSKAYA, DD. and RACHMANOVA, VI. Oligodendroglial density in the prefrontal cortex in schizophrenia and mood disorders: a study from the Stanley Neuropathology Consortium. Schizophrenia Research, 2004, vol. 67, n. 2-3, p. 269-275. http://dx.doi.org/10.1016/S0920-9964(03)001816. PMid:14984887.

VAN DER JEUGD, A., AHMED, T., BURNOUF, S., BELARBI, K., HAMDAME, M., GROSJEAN, ME., HUMEZ, S., BALSCHUN, D., BLUM, D., BUÉE, L. and D'HOOGE, R. Hippocampal tauopathy in tau transgenic mice coincides with impaired hippocampus-dependent learning and memory, and attenuated late-phase long-term depression of synaptic transmission. Neurobiology of Learning and Memory, 2011, vol. 95, n. 3, p. 296-304. http://dx.doi.org/10.1016/j. nlm.2010.12.005. PMid:21167950.

ZUO, DY., WU, YL., YAO, WX., CAO, Y., WU, CF. and TANAKA, $M$. Effect of MK-801 and ketamine on hydroxyl radical generation in the posterior cingulate and retrosplenial cortex of free-moving mice, as determined by in vivo microdialysis. Pharmacology, Biochemistry, and Behavior, 2007, vol. 86, n. 1, p. 1-7. http://dx.doi.org/10.1016/j. pbb.2006.05.010. PMid:16806445.
Received October 6, 2015

Accepted July 25, 2016 